\title{
Phytoprotection
}

\section{Invasion of the Carribean by the hibiscus mealybug, Maconellicoccus hirsutus Green [Homoptera : Pseudococcidae]}

\section{L.A. Sagarra et D.D. Peterkin}

Volume 80, numéro 2, 1999

URI : https://id.erudit.org/iderudit/706185ar

DOI : https://doi.org/10.7202/706185ar

Aller au sommaire du numéro

Éditeur(s)

Société de protection des plantes du Québec (SPPQ)l

ISSN

0031-9511 (imprimé)

1710-1603 (numérique)

Découvrir la revue

Citer cet article

Sagarra, L. \& Peterkin, D. (1999). Invasion of the Carribean by the hibiscus mealybug, Maconellicoccus hirsutus Green [Homoptera : Pseudococcidae]. Phytoprotection, 80(2), 103-113. https://doi.org/10.7202/706185ar
Résumé de l'article

Since its accidental introduction into the island of Grenada in 1994 Maconellicoccus hirsutus [Homoptera : Pseudococcidae], commonly named the Hibiscus or Pink Mealybug (HMB), has been inexorably spreading through the Caribbean islands where it has become a major pest on several crops in 24 Caribbean Islands. This pest was also reported in Guyana threatening South and Central America. M. hirsutus is a very prolific pest that injects a toxin at the point of feeding, causing severe distortion of leaves, new shoots and fruit. Initial use of physical and chemical control methods were ineffective. In addition, because of its wide host range and its rapid geographie expansion, not only to agricultural land but also to home gardens and forest areas, biological control appeared as the most suitable method to manage the HMB populations. Three natural enemies were selected for this biocontrol effort: the predatory beetles Cryptolaemus montrouzieri Mulsant and Scymnuscoccivora Ramkrisna [Coleoptera : Coccinellidae] and the parasitoid Anagyruskamali Moursi [Hymenoptera : Encyrtidae]. A. kamali and C. montrouzieri were highly effective in bringing HMB populations under control. In newly infested countries, early introduction of biological control agents resulted in effective management of the pest. This experience provided a model for future management of other alien invasive pest species in the region. 


\title{
Invasion of the Caribbean by the hibiscus mealybug, Maconellicoccus hirsutus Green [Homoptera : Pseudococcidae]
}

\author{
L.A. Sagarra ${ }^{1}$ and D.D. Peterkin ${ }^{2}$ \\ ${ }^{1}$ P-R Trinidad Ltd., Orange Grove Estate, Tacarigua, Trinidad \& Tobago - W.I.; e-mail: \\ saga@wow.net \\ ${ }^{2}$ CABI Bioscience, Gordon Street, Curepe, Trinidad \& Tobago - W.I.
}

PHYTOPROTECTION 80: 103-113

\section{ABSTRACT}

Since its accidental introduction into the island of Grenada in 1994, Maconellicoccus hirsutus [Homoptera : Pseudococcidae], commonly named the Hibiscus or Pink Mealybug (HMB), has been inexorably spreading through the Caribbean islands where it has become a major pest on several crops in 24 Caribbean Islands. This pest was also reported in Guyana threatening South and Central America. M. hirsutus is a very prolific pest that injects a toxin at the point of feeding, causing severe distortion of leaves, new shoots and fruit. Initial use of physical and chemical control methods were ineffective. In addition, because of its wide host range and its rapid geographic expansion, not only to agricultural land but also to home gardens and forest areas, biological control appeared as the most suitable method to manage the HMB populations. Three natural enemies were selected for this biocontrol effort: the predatory beetles Cryptolaemus montrouzieri Mulsant and Scymnus coccivora Ramkrisna [Coleoptera: Coccinellidae] and the parasitoid Anagyrus
\end{abstract}

kamali Moursi [Hymenoptera : Encyrtidae]. A. kamali and $C$. montrouzieri were highly effective in bringing $\mathrm{HMB}$ populations under control. In newly infested countries, early introduction of biological control agents resulted in effective management of the pest. This experience provided a model for future management of other alien invasive pest species in the region.

\section{INVASIVE PESTS IN THE CARIBBEAN}

The threat posed by introduced pests (insects, plant diseases and weeds) reaches far beyond traditional agricultural production. The advent of an invasive species into a new environment may impact on economic activities and trade. It may also have far reaching ecological consequences in terms of alterations to biodiversity and the function of natural communities of organisms.

In a new environment, exotic invasive species are usually free from the burden of pre-adapted predators, parasites, pathogens and competitors that

Note du rédacteur : le texte ci-dessus est présenté tel que soumis / Editor's note : the above text is presented as submitted. 
kept them in check in their native habitat. They multiply and spread explosively, rapidly colonizing and dominating the new environment. This is particularly true in the Caribbean, where each island ecosystem has a specific flora and fauna which are unusually susceptible to damage by invasive species. Introduction of exotic species is a threat to the indigenous species which could be displaced or even eradicated due to competition with the new species (Van Driesche and Bellows 1993). This could affect the entire balance of an ecosystem since the development of the new species is virtually uncontrolled and geographical barrier may prevent the natural introduction of pre-adapted competitors from its area of origin. This was the case when the mongoose was introduced into the Caribbean to control snake populations in commercial crop plantations. In this new environment, mongoose populations increased to such extent that they are now threatening certain local snake species which were previously controlling populations of rodents in the islands.

Over the last decade, the Caribbean has been invaded by several species of exotic insect pests. These include the melon thrips, Thrips palmi, and the mango seed weevil, Sternochetus mangiferea, from Asia, and the brown citrus aphid, Toxoptera citricida, which is the most important vector of the citrus tristeza virus, from South Africa via South America. More recent invasions are represented by species like the citrus leaf miner, Phyllocnistis citrella, originally from Asia and Africa, and the citrus black fly, Aleurocanthus woglumi, from South America.

Two important mealybug species were also accidentally introduced into the region within the last 5 years, and moved rapidly through the islands: Maconellicoccus hirsutus, the hibiscus mealybug from Asia, and Paracoccus marginatus from South America (Matille-Ferrero and Etienne 1998).

This paper will focus on the impact of $M$. hirsutus as a recent invasive pest in the Caribbean.

\section{INTRODUCTION AND SPREAD OF M. HIRSUTUS IN THE CARIBBEAN}

Maconellicoccus hirsutus Green [Homoptera: Pseudococcidae], commonly named the Hibiscus or Pink Mealybug (HMB), was first described in India by Green (1908) as Phenacoccus hirsutus and was subsequently placed in the genus Maconellicoccus by Ezzat in 1958. It originated from South East Asia (Williams 1996) and prior to 1994, it was widely distributed in numerous countries of the inter-tropical areas of Africa, Asia and Australia (I.I.E. 1997). M. hirsutus was first recorded in the Western hemisphere in November 1994, from the island of Grenada in the Caribbean (Matille-Ferrero and Etienne 1996), where it was possibly introduced several years earlier. The origin of the pest introduction is still unknown.

$M$. hirsutus rapidly spread through the Caribbean, increasing its geographical range from one island in 1994 to four islands in 1995, 7 islands in 1996, 17 islands in 1997, 20 islands in 1998 and 21 islands in 1999 (Pollard 1998; Etienne, personal communication).

The pest is now present in Grenada, Trinidad, St. Kitts and Nevis, Saint Maarten, Saint Lucia, Tobago, St. Eustatius, Curaçao and possibly Aruba, Anguilla, Guyana, British Virgin Islands, St. Vincent and the Grenadines, US Virgin Islands, Viequez and Culebra Islands of Puerto Rico, Monserrat, Guadeloupe, Puerto Rico mainland, and most recently Martinique was reported to be infested. To date, the only uninfested islands of the Lesser Antilles are Barbados, Dominica and Antigua and Barbu$\mathrm{da}$, but the probability of these remaining uninfested is slim.

$M$. hirsutus generally entered uninfested areas through the ports on contaminated produce or hidden in passenger luggage. It rapidly spread along the main routes of human traffic. This pattern was repeated in most of the infested countries. The hibiscus mealybug was also spread by wind, animals, 
rainfall, human activities and vehicles. In Guyana, the mealybug first spread within the urban areas and then along the rivers which are used as main routes for human traffic.

\section{BIOLOGY OF M. HIRSUTUS}

Like many phytophagous homoptera, $M$. hirsutus is a sucking insect. Each female deposits between 84 to 654 eggs during 4 to 8 days. The eggs hatch in $3-$ 9 days and a generation is usually completed within a month (23-35 days) (Table 1). Eggs are laid in a loose cottony terminal ovisac, and are orange to pink (Ghose 1972). Newly hatched mealybugs (crawlers) are very mobile, they settle on the host and start developing. This stage is inconspicuous and is responsible for the rapid spread of the pest from initial sites of infestation. Females have three and males have four nymphal instars (Mani 1988). Adult males have one pair of wings, and two long waxy caudal filaments at the posterior end of the abdomen. The adult females are wingless, dark pink and sparsely covered with white waxy filamentous secretion (Mani 1986). After the completion of egg laying, the female mealybug shrinks considerably and ultimately dies. Mani (1986) and Hall (1921) reported both sexual and parthenogenetic reproduction.

\section{HOST PLANTS AND DAMAGE OF M. HIRSUTUS}

Maconellicoccus hirsutus is an extremely polyphagous species. It affects a total of 200 plants species around the world (Berg 1996). In Egypt, severe mealybug infestations were observed on Hibiscus spp. (including cotton), mulberry and Albizzia lebbek. In all these species, terminal shoots were destroyed giving the plants a gnarled appearance (Mani 1989). In India, it is a severe pest on

Table 1. Summary of biological data on Maconellicoccus hirsutus (Sagarra 1999)

\begin{tabular}{|c|c|c|c|c|c|c|c|}
\hline Particulars & $\begin{array}{l}\text { Misra } \\
\text { (1919) }\end{array}$ & $\begin{array}{l}\text { Hall } \\
(1921)\end{array}$ & $\begin{array}{l}\text { Dutt et al. } \\
\text { (1951) }\end{array}$ & $\begin{array}{c}\text { Singh and } \\
\text { Ghosh } \\
(1970)\end{array}$ & $\begin{array}{l}\text { Ghose } \\
(1972)\end{array}$ & $\begin{array}{l}\text { Mani } \\
(1986)\end{array}$ & $\begin{array}{c}\text { Reddy } \\
\text { and } \\
\text { Narayana } \\
(1986)\end{array}$ \\
\hline \multicolumn{8}{|c|}{ Egg size } \\
\hline (Length -mm) & $0.36-0.39$ & - & $0.29-0.32$ & - & $0.36-0.40$ & $0.34-0.38$ & - \\
\hline (Width -mm) & $0.15-0.21$ & - & 0.17 & - & $0.18-0.21$ & $0.17-0.20$ & - \\
\hline $\begin{array}{l}\text { Incubation } \\
\text { (days)4 }\end{array}$ & $5-8$ & $6-9$ & 7 & $6-7$ & $3-8$ & $4-7$ & $3-4$ \\
\hline $\begin{array}{l}\text { Nymph } \\
\text { (days) }\end{array}$ & - & - & - & 22 & $10-19$ & $19-22$ & $20-25$ \\
\hline $\begin{array}{l}\text { Eggs to adult } \\
\text { (days) }\end{array}$ & $24-29$ & 35 & - & - & $23-29$ & $24-27$ & 30 \\
\hline $\begin{array}{l}\text { Adult length } \\
\text { (mm) }\end{array}$ & 2.52 & - & 3 & - & - & $2.65-2.80$ & - \\
\hline $\begin{array}{l}\text { Preoviposition } \\
\text { (days) }\end{array}$ & - & - & - & $3-5$ & $0.5-6$ & $4-5$ & - \\
\hline $\begin{array}{l}\text { Oviposition } \\
\text { (days) }\end{array}$ & - & - & $5-8$ & $4-5$ & - & $6-8$ & - \\
\hline $\begin{array}{l}\text { Fecundity } \\
\text { (No. of eggs/ } \\
\text { female) }\end{array}$ & 232 & $150-300$ & 194 & - & $84-654$ & $386-540$ & 500 \\
\hline
\end{tabular}


fiber crops like jute, mesta, roselle, etc. and also on grapevine. Infestation of the growing point resulted in malformation of shoots and leaves (Mani 1988). In Saudi Arabia, the hibiscus mealybug was found infesting Date Palm fruits, living in large masses on the middle stands of the fruit bunches (Talhouk 1993). M. hirsutus also affects a wide range of other crops of economic importance including citrus, cocoa, coffee, legumes, grapes, etc. (Berg 1996).

It is worth noting that in its area of origin the host range is restricted to relatively few plant species (Mani 1989) whereas in the Caribbean, over 150 species of tree crops, vegetables, root crops, ornamentals, forest trees and weeds are affected by $M$. hirsutus (Table 2). The most commonly affected plants are members of the family Malvaceae including ornamental hibiscus, sorrel and okra. A number of orchard crops such as Citrus spp. and Annona spp. have also been affected. Many large economically important species of tree such as Blue Mahoe (Hibiscus elatus), Samaan (Samanea saman), Teak (Tectona grandis) and Gliricidia spp. have shown extreme susceptibility to this pest, and many Blue Mahoe and Samaan trees have died from high infestation. Hosts may be divided into two categories, i.e., 1) those on which the pest can complete its development (e.g. hibiscus, okra, sorrel, samaan, etc.) and 2 ) those on which $M$. hirsutus can feed and produce damage symptoms but does not complete development (e.g., green peper, tomatoes, egg plant, etc.).

The hibiscus mealybugs form colonies with a very low mobility (Dufour and Leon 1997). The insect is gregarious in habit. Both adults and larval instars move to the soft succulent parts of the plants, infesting tender shoots, buds, petioles and leaf lamina. During high infestation, they can even remain on the main stem of young plants (Singh and Ghosh 1970). As a result of its feeding action, the mealybugs inject toxic saliva into the plant, provoking characteristic symptoms: leaf curling, fruit malformation, bunchy top appearance, etc., due to modification of the growth including the shortening of internodes. The degree of the symptoms depends on the sensitivity of the crop. Heavy infestation may cause a complete defoliation of the plant, leading to their death (Dufour and Leon 1997). The production of honeydew by the pest can also cause development of sooty mould.

\section{POTENTIAL ECONOMIC LOSSES OF M. HIRSUTUS IN THE CARIBBEAN}

The economic and ecological consequences of mealybug infestation through the Lesser Antilles could have been disastrous. The HMB could spread to all of the Caribbean Islands and also South America. Export of fresh fruits and flowers from the infested area have been restricted, threatening regional trade in agricultural products. Hotels have experienced increased cost for landscaping and replacement of the infested hibiscus and other ornamental plants. Finally, the timber industry and watersheds are also under the threat of the pink mealybug since the pest affects several important species of forest trees. In 1997, USDA estimated that economic losses exceeded US \$3.5 million a year in Grenada and US \$125 million a year in Trinidad and Tobago before control measures were implemented (USDA 1997).

An economic study conducted by $L$. Joe Moffit from the University of Massachussets (1999-unpublished data) showed that the economic risk to United States agriculture in the event of invasion of Hibiscus Mealybug is estimated to be approximately US $\$ 750$ million per year in the absence of control measures. The agricultural crops in the mainland United States expected to bear most of the economic risk include ornamental crops, vegetable crops, citrus crops, grapes and avocados. 
Table 2. List of plants on which the hibiscus mealybug has been recorded in Trinidad (after Mc Comie 1998)

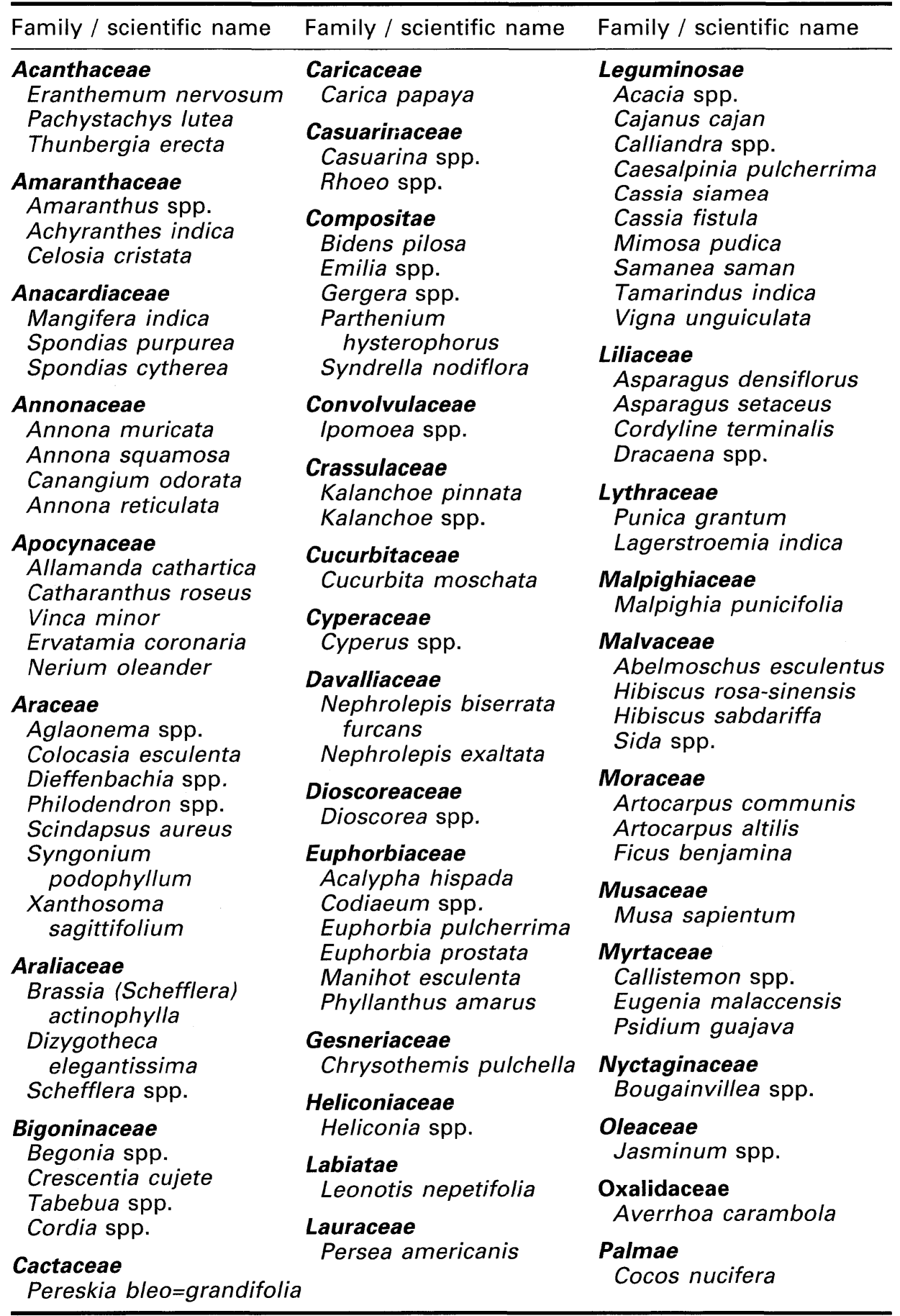


Table 2. List of plants on which the hibiscus mealybug has been recorded in Trinidad (after Mc Comie 1998) (Continued)

\begin{tabular}{llc}
\hline Family / scientific name & Family / scientific name & Family / scientific name \\
\hline Passifloraceae & Rubiaceae & Umbelliferae \\
Passiflora edulis & Ixora spp. & Eryngium foetidum \\
Picrodendraceae & Hamelia spp. & Urticacaeae \\
Picrodendron baccatum & Mussaenda spp. & Laportea aestuans \\
Piperaceae & Rutaceae & Verbenaceae \\
Piper tuberculatum & Aegle marmelos & Lantana camara \\
Piperonia pellucida & Citrus spp. & Stachytarpheta \\
Polygonaceae & Murraya paniculata & jamaicensis \\
Coccoloba uvifera & Murraya koenigii & Stachytarpheta spp. \\
Portulacaceae & Sapindaceae & Vitaceae \\
Portulaca oleraceae & Blighia sapida & Cissus verticillata \\
Portulaca pilosa & Meliococca bijuga & Vitis vinifera \\
Grevillea robusta & Scrophulariaceae & Zingiberaceae \\
Rhamnaceae & Scoparia dulcis & Alpinia spp. \\
Ziziphus mauritiana & Solanaceae & \\
Rosaceae & Capsicum frutescens & \\
Rosa spp. & Datura spp. & \\
& Solanum melongena & \\
\hline
\end{tabular}

\section{CONTROL METHODS OF M. HIRSUTUS IN THE CARIBBEAN}

To counteract the Hibiscus Mealybug infestation into the Caribbean, three control strategies were subsequently implemented:

\section{Plant quarantine measures and awareness campaign in non infested countries}

Following the introduction of the mealybug from Grenada to Trinidad, quarantine systems were strengthened and upgraded in all the neighbouring countries to prevent or delay the introduction of the pest. Legislation was enacted in several countries, for example, in Trinidad and Tobago, $M$. hirsutus was proclaimed to be a "Notifiable Pest" in October 1995. This was followed by the revision of the plant protection regulations and the increased surveillance at ports of entry. Regional plant protection officers were trained in Trinidad to identify mealybug species. A regional public awareness campaign for the West Indies was conducted to increase the consciousness on the part of the public and to consequently decrease illegal trading and contraband by exporters, importers and passengers.

The impact of these measures was limited since 20 additional islands were infested between 1996 and 1998, and to date, only four islands of the Lesser Antilles remain uninfested.

\section{Physical and chemical control}

When $M$. hirsutus was first identified in the Caribbean, it was initially thought that the pest could be eradicated. Eradication efforts focused on the use of pesticides combined with cultural methods, mainly burning of crop residue. In Grenada, 90 ha of Blue Mahoe were felled in an effort to contain the spread of the pest. However, it was realized that while pesticides gave a quick knockdown, rapid reinfestations by $M$. hirsutus occurred necessitating spray cycles every 2 to 3 weeks. A number of chemicals and mixtures have been used over the years in attempts to control HMB infestations. Chemical control of the pest has proved to be difficult since mealybugs tend to inhabit less accessible 
areas such as cracks and crevices of bark, inside fruit bunches and growing points. The mealybugs are also covered with a waterproof secreted waxy coating, and its eggs are laid into an ovisac made up of a knotted mass of long waxy filaments preventing the penetration of water-based sprays. Another problem was the wide host range and large size of infested hosts. It is almost impossible to have a spraying programme that can bear the cost and cope with the practicalities of treating the whole range of infested plants in an affected area.

Cutting and burning of heavily infested material were also recommended to follow the pesticide application, but reluctance to the continuous use of pesticides led households to concentrate on the cutting and burning of shrubs and trees.

The pest continued to spread despite the chemical and physical control measures, the wide scale use of pesticides for the control of $M$. hirsutus was gradually phased out with the systematic release of biological control agent in the environment.

\section{Biological control}

All organisms have natural enemies and hence are potential targets for biological control. This is particularly true for invasive pest species like $M$. hirsutus which arrived in the Caribbean without its specific natural enemies and was able to multiply virtually unchecked.

Following the limited success of physical and chemical measures to control the pest populations, regional biological control programs for $M$. hirsutus were initiated in 1996. This should ensure a long-term suppression and control of this pest, and also reduce considerably costs associated with chemical control.

The exotic nature of the mealybug, and the known effective natural enemy complex from its probable area of origin, indicated that classical biological control would be the most appropriate long-term strategy. In such a program, an exotic natural enemy (or enemies) is introduced into the recipient country usually from the pest's area of origin.

\section{Previous biological control programmes}

Similar programs to control M. hirsutus infestation have already been conducted in Egypt and India.

In Egypt, two coccinellids species and several hymenopterous parasitoids were released in attempts to control $M$. hirsutus in the 1930s. The lady beetle, Cryptolaemus montrouzieri was imported from Australia and reared in insectaries for periodic releases in Egypt. Although the predator eventually became established, it did not perform well because there was very poor survival over the Egyptian winter. Another coccinellid, Scymnus conformis, was introduced from Indonesia (Java) but this species did not establish. Several parasitoids were introduced from Indonesia (Java) throughout the 1930s and of these Leptomastix phenacocci has been reported as becoming established. However, M. hirsutus control has been attributed to the release of Anagyrus kamali, with figures of parasitisation from field samples ranging from 6698\% (Kamal 1951). In many areas, it was reported that the mealybug was almost eradicated.

Another success has been achieved with the release of the coccinellid predators in India in the 1970s. Cryptolaemus montrouzieri was released at a number of vineyards in southern India and was reported as achieving effective control of HMB (Mani 1989). C. montrouzieri has often been used for the biological control of mealybugs, and is usually effective at high pest densities. Other coccinellid species, Scymnus coccivora Ramkrishna Ayyar and Scymnus gratiousus Wiese, which survive at lower population levels of the mealybug and have lower temperature thresholds, have also been recommended for release in addition to $C$. montrouzieri. Two Anagyrus species, Anagyrus dactylopii and Anagyrus kamali, have also been reported as being key natural enemies of the mealybug, achieving parasitisation rates of $60-70 \%$ in the field in late season (Mani 1989).

Finally, in Hawaii, after initial heavy infestations were noted on cultivated hibiscus and Erythrina spp. population 
numbers dropped, in the presence of parasitoids, to low levels that damage was no longer noted. The parasitoids were fortuitously introduced with the pest and lately identified as $A$. kamali (Beardsley 1985).

\section{Caribbean biological control program}

In view of the above, several Caribbean countries have implemented biological control programmes against the Hibiscus Mealybug. These have been joint efforts involving National Programmes with assistance from regional and international organizations like FAO, CARDI, CABI Bioscience, IICA, the USDA and INRA.

Initially, when the mealybug was only present in Grenada, a FAO TCP program was launched to provide Grenada with the parasitoid wasp, A. kamali, produced in the UK by CABI Bioscience. Following the pest spreading through the Caribbean, the parasitoid A. kamali was imported from China and locally mass-produced in Trinidad for releases in the region. This mass-production programme of $A$. kamaliwas part of the technical cooperation project funded by $\mathrm{FAO}$, the actual rearing being conducted at CABI Bioscience in Trinidad. The parasitoid was introduced into Grenada, Trinidad and Tobago, St. Kitts and
Nevis, St. Martin, Guyana, St. Lucia, US and British Virgin Islands, Guadeloupe, Curaçao, St. Vincent and the Grenadines, and Montserrat. The numbers of natural enemies released in the different countries are presented in Table 3.

In addition, St. Kitts and Nevis, Puerto Rico (including Viequez and Culebra) and the US Virgin Islands have also released a population of $A$. kamali from Hawaii and Gyranusoidea indica from Egypt provided by USDA (Meyerdirk, personal communication). In Puerto Rico, only parasitoids were released to control the mealybug.

The predatory beetle, $C$. montrouzieri, was imported from India and/or the USA and have been introduced into all of the infested countries. C. montrouzieri has also been released in Barbados although the Hibiscus Mealybug is not yet present in the country. Mass-production was first conducted but it appeared to be less cost efficient than direct imports of beetles from the USA.

Another predatory coccinellid, Scymnus coccivora was also imported from India and released into Grenada, Trinidad and Tobago, St. Kitts and Nevis, and Montserrat. However, Scymnus coccivora appeared to have little impact on suppressing HMB.

Table 3. Natural enemies releases in the Caribbean

\begin{tabular}{lcccc}
\hline Country & \multicolumn{4}{c}{ Number of natural enemies releases } \\
\cline { 2 - 5 } & C. montrouzieri & S. coccivora & A. kamali & G. indica \\
\hline British Virgin Islands & 18000 & - & 9500 & - \\
Curaçao & 2000 & 1925 & 25000 & 1500 \\
Grenada & 56000 & - & 15240 & - \\
Guyana & 500 & 500 & 9250 & - \\
Montserrat & 206300 & 1300 & 66000 & 32000 \\
St. Kitts and Nevis & 406000 & - & 44525 & - \\
St. Lucia & 85416 & - & 25330 & - \\
St. Vincent & 30000 & 9000 & 43670 & - \\
Trinidad and Tobago & 000000 &
\end{tabular}

Source: country reports presented at the FAO Evaluation workshop on the biological control of the pink hibiscus mealybug, Maconellicoccus hirsutus, in the Caribbean, Trinidad, March 1999. 


\section{IMPACT OF THE BIOLOGICAL CONTROL PROGRAM IN THE CARIBBEAN}

Initial results from Grenada, Trinidad and Tobago, St. Kitts and Nevis and St. Lucia indicated that $A$. kamali and $C$. montrouzieri have become established and have dispersed from their initial release sites and are effectively controlling populations of $M$. hirsutus. There is little information on the impact of $S$. coccivora. At present, mealybug populations are reported as generally low in these islands, with the mealybug occurring in significant numbers on approximately 15 plant species.

The general strategy has been the introduction of $C$. montrouzieri when pest populations were high, followed by releases of $A$. kamali to maintain the pest at a low population. Such an approach has been suggested for control of other mealybug species (Greathead 1977; Panis 1981).

Recently, there has been much controversy on the indiscriminate introduction of natural enemies for classical biological control since such introduction could disrupt existing natural enemy complexes of indigenous pests. This is particularly relevant where the inherently fragile ecosystem of small island developing states are concerned. Such introduction should be supported by sound ecological studies on the biology and host selection of the exotic natural enemies. The extent to which species introduced for biological control attacks non-target species and the ecological consequences of such attacks are matters of serious concern. Careful assessment of biocontrol agents and effective means of host testing is necessary prior to their introduction to ensure that nontarget effects are minimized.

Host species selection tests were conducted for the parasitoid $A$. kamali in choice and non-choice situation using nine major species of Caribbean mealybug. These included Planococcus citri (Risso), Planococcus halli Ezzat \& McConnel, Dysmicoccus brevipes (Cockerell), Pseudococcus elisae Borchsenius,
Saccharococcus sacchari (Cockerell), Puto barberi (Cockerell), Nipaecoccus nipae (Newstead), Plotococcus neotropicus Williams \& Granara de Willink and $M$. hirsutus. Out of nine species of mealybugs present in the region, $A$. kamali could only develop successfully from M. hirsutus (Sagarra 1999). Such specificity of the introduced natural enemy should have minimal consequences on non-target species.

\section{CONCLUSION}

During the early phase of $M$. hirsutus infestation in the Caribbean, in the absence of exotic natural enemies from the pest's area of origin, the mealybug had attacked numerous host plants, causing extensive damage to a wide range of agricultural, forestry and ornamental crops. Since then, the regional programmes were implemented for biological control of HMB. Although 11 new countries were infested by the pest since then, tremendous damage, as observed in Grenada, Trinidad or St. Kitts and Nevis during the initial stage of infestation by HMB, was not subsequently observed. This could be explained by the early introduction of natural enemies, principally $A$. kamali and $C$. montrouzieri, once the pest was detected in a new country and its identity confirmed. In the presence of its natural enemies, $M$. hirsutus rarely caused significant damage. Its host range was considerably reduced, as remaining populations could only be found on a few preferred host species of Malvaceae, Annonaceae and Leguminaceae. To sustain their biological control effort, several Caribbean countries are developing mass-rearing facilities for natural enemies of HMB to continue producing $A$. kamali after the termination of the regional program.

The sociological impact of HMB infestation has also been tremendous as awareness campaigns were conducted in all the Lesser Antilles Islands to inform the population about this problem. People have been educated concerning biological control and now understand that spraying their infested 
hibiscus plants will not eradicate mealybugs and that they have to let the natural enemies "do their job". In Trinidad, telephone hotlines were installed for the public to obtain free information and natural enemies from the Ministry of Agriculture. At the regional level, the HMB program is the first regional biological control program, and its success may open the doors for further cooperative projects in that domain. Several new pests species are spreading through the region (Paracoccus marginatus Williams and Granara de Willink, Aleurocanthus woglumi the citrus black fly, and Phyllocnistis citrella the citrus leaf miner) and some of the experiences gained during the programme for regional biological control of HMB may be directly applied to finding solutions to problems caused by these and future invasive pests. National, regional, and international efforts to curtail the invasions are fundamental to decrease the impact of exotic species on human society and the environment.

\section{ACKNOWLEDGEMENT}

We thank C. Vincent, Horticulture Research and Development Research Center, Agriculture and Agri-Food Canada, Saint-Jean-sur-Richelieu, Québec, Canada, for commenting an early version of the manuscript.

\section{REFERENCES}

Beardsley, J.W. 1985. Pseudococcidae. In C.P. Clausen (ed.), Introduced Parasites and Predators of Arthropod Pests and Weeds, a world review. U.S. Dept. Agric. Handbook 480 : 137-169.

Berg, G.H. 1996. Analisis de riesgo por una via respecto a Maconellicoccus hirsutus (Green) (cochinilla rosada), a nivel global. Informe tecnico, OIRSA, EI Salvador. $32 \mathrm{pp}$.

Dufour, B.P., and J. Leon. 1997. Informe de mission de informacion sobre el control de la cochinilla rosada del hibisco ( $M a-$ conellicoccus hirsutus Green) en la region del Caribe. IICA - El Salvador, 22 pp.
Dutt, N., P.K. Mukerjee, and N. Sen Gupta. 1951. Preliminary observations on the incidence of Phenacoccus hirsutus Green and its effect on the growth of Hibiscus sabdariffa L. and V. altissima Hort. Indian J. Agric. Sci. $21:$ 231-237.

Ezzat, Y.M. 1958. Maconellicoccus hirsutus Green, a new genus with redescription of the species (Homoptera : Pseudococcidae - Coccoidea). Bull. Soc. Entomol. Egypt 42 : 377-388.

Ghose, S.K. 1972. Biology of the mealybug Maconellicoccus hirsutus (Green) (Pseudococcidae : Hemiptera). Indian Agric. 16 : 323-332.

Greathead, D.J. 1977. Biological control of mealybug (Homoptera: Pseudococcidae) with special reference to the cassava mealybug (Phenacoccus manihoti Mat.Ferr.). Pages 70-80 in K.F. Nwanze and K. Leuschner (eds.), Proceedings of the International Workshop on the cassava mealybug, Phenacoccus manihoti Mat.Ferr. (Pseudococcidae). INERA-M'vuazi, Bas Zaire, Zaire. 26-29 June 1997.

Green, E.E. 1908. Remarks on Indian Scale Insects (Coccidae), part III. With a catalogue of all species hitherto recorded from the Indian continent. Mem. Dep. Agric. Indian Ent. Ser. 2 : 15-46.

Hall, W.J. 1921. The Hibiscus Mealybug, Pseudococcus hibisci (Hemip.). Bull. Soc. Entomol. Egypt 14 : 17-29.

I.I.E. (International Institute of Entomology) 1997. Distribution map of pest, series $A$ (Agricultural) map \#100 (2nd revision) Maconellicoccus hirsutus.

Kamal, M. 1951. Biological control projects in Egypt, with a list of introduced parasites and predators. Bull. Soc. Fouad 1er Entomol. 35 : 205-220.

Mani, M. 1986. Distribution, bioecology and management of the grape mealybug Maconellicoccus hirsutus (Green) with a special reference to its enemies. Ph.D. thesis, UAS, Bangalore.

Mani, M. 1988. Bioecology and management of grapevine mealybug. Ind. Inst. Hortic. Res. - Tech. Bull. No. 31 pp.

Mani, M. 1989. A review of the pink mealybug - Maconellicoccus hirsutus (Green). Insect Sci. Applic. 10 : 157-167.

Matile-Ferrero, D., and J. Etienne. 1996. Présence de la cochenille de l'hibiscus, Maconellicoccus hirsutus à Saint-Martin (Hemiptera : Pseudococcidae). Rev. Fr. Entomol. $18: 38$. 
Matile-Ferrero, D., and J. Etienne. 1998. Paracoccus marginatus Williams \& Granara de Willink, nouvelle introduction en Guadeloupe et à Saint-Barthélemy (Hemiptera : Pseudococcidae). Rev. Fr. Entomol. $20: 148$.

Mc Comie, L. 1998. Incidence and treatment of the hibiscus mealybug Maconellicoccus hirsutus (Green) in Trinidad. Proceeding of the 1st seminar on the hibiscus mealybug, April 1998, Trinidad.

Misra, C.S. 1919. "Tukra" disease of mulberry. Proc. 3rd Entomol. Meet., Pusa. p. 610-618.

Panis, A. 1981. Note sur quelques insectes auxiliaires régulateurs des populations de Pseudococcidae et Coccidae (Homoptera : Coccidea) des agrumes en Provence orientale. Fruits 36 : 49-52.

Pollard, G.V. 1998. Update on new pest introductions. Circular Letter No. 3/98 FAO.

Reddy, R.A. and L.K. Narayana. 1986. Biology and control of grape mealybug. Indian Grape J. 2 : 30-39.
Sagarra, L.A. 1999. Biology and behaviour of Anagyrus kamali Moursi [Homoptera : Pseudococcidae]. Ph.D. Thesis, McGill University, Montreal, Canada.

Singh, M.P., and S.N. Ghosh. 1970. Studies on Maconellicoccus (Phenacoccus) hirsutus Gr. causing "bunchy top" in Mesta. Indian J. Sci. and Indust. 4 : 99-105.

Talhouk, A.S. 1993. Some insect species injurious to crops in Middle East Countries. J. Appl. Entomol. 116 : 105-111.

USDA. 1997. The pink hibiscus mealybug. USDA Publication. Florida, USA.

Van Driesche, R.G., and T.S. Bellows. 1993. Steps in classical arthropod biological control. Thomas Say publications in entomology : proceedings. Maryland, USA.

Williams, D.J. 1996. A brief account of the hibiscus mealybug Maconellicoccus hirsutus (Hemiptera : Pseudococcidae), a pest of agriculture and horticulture, with descriptions of two related species from southern Asia. Bull. Entomol. Res. 86 : 617-628. 